\title{
Epileptic events in the XIX century as reported by the Brazilian Royal Family
}

\author{
Marleide da Mota Gomes', Heber de Souza Maia-Filho²
}

\begin{abstract}
Members of the Brazilian Royal Family carry a rich medical history of epileptic seizures and alike. Objective: To present the medical knowledge about epilepsy by the time of the Brazilian Empire, as reported by the royal family. Method: Narrative review of historical facts about D. Pedro I's family health. Results: The Royal Family, since D. João VI's generation is full of members with epilepsy or acute symptomatic seizures of different etiologies. Conclusion: The reported cases suggest that Dom Pedro I's family presented epilepsy with tonic-clonic generalized seizures, besides psychogenic, organic non epileptic events and acute symptomatic seizures. As a whole, this familial epilepsy could fit the diagnosis of generalized epilepsy with febrile convulsion plus.
\end{abstract}

Key words: epilepsy, genetics, generalized epilepsy with febrile convulsion plus, history, medicine, Brazil.

\section{Eventos epilépticos no século XIX segundo relatos da Família Real Brasileira}

\section{RESUMO}

Há uma história médica rica de crises epilépticas e similares nos membros da família real brasileira. Objetivo: Apresentar o conhecimento médico sobre epilepsia à época do Império no Brasil, conforme informado pelos acometidos da família real. Método: Revisão narrativa de fatos históricos sobre a saúde da família de D. Pedro I. Resultados: A genealogia da família real, desde a geração de D. João Vl é repleta de pessoas acometidas por epilepsia ou crises sintomáticas agudas de diversas etiologias. Conclusão: $\bigcirc$ relato de casos sugere que Dom Pedro I e sua família apresentavam epilepsia de incidência familiar predominantemente com crises tônico-clonicas generalizadas, além de eventos sintomáticos agudos, psicogênicos e orgânicos não epilépticos. Como um todo, a epilepsia dessa família poderia ser enquadrada no diagnóstico de epilepsia generalizada com convulsão febril plus.

Palavras-chave: epilepsia, genética, epilepsia generalizada com convulsão febril plus, história, medicina, Brasil.

Souza ${ }^{1}$ reports that the majority of the Brazilian royal family had "nervous illnesses", particularly the women, of whom many had convulsive seizures. The frequency of epileptic seizures and syndromes alike in Dom Pedro I's family was recognized ${ }^{2-5}$. We recover the historical royal family reports to illustrate the epilepsy medical knowledge of that time.

\section{Familiar incidence}

The emperor Dom Pedro I, according to Souza", spoke about his "epileptic seizures as a minor event, attributing it as a disease with origin in the House of Spain". Macaulay ${ }^{6}$ confirms this familiar incidence: "Except for the common inheritance of epilepsy, Dom Pedro I seem to have escaped from a variety of illnesses that afflicted his 
brothers..." Morocco (amanuensis of the Crown) reported in his letters, in October, 1811, apud Souza ${ }^{1}$, concerning the sons of the Bourbon and Bragança couple, Dom João and Dona Carlota Joaquina, that the whole family had "perfect health, except boys and girls, who presented seizures, especially Mrs. Dona Maria Isabel” (D. Pedro I's sister). In September, 1813, he informs that Dona Maria Isabel was very sick of "her accidents and faints". Her mother, Dona Carlota Joaquina, told her brother, Dom Fernando VII, on May $23^{\text {rd }}, 1814$, describing Maria Isabel "...17 years old, fat and white; having had for four years very strong epileptic events". Dona Maria Isabel died in tragic conditions. Only on March, 1819, three months after her death, the royal family in Brazil knew the details, as according to Macaulay ${ }^{6}$ : "In the last pregnancy months, she had an epileptic attack and went into coma, confused as death or, at least, with the agony of death. The expected child was supposed to be the long time waited male heir. Anxious for saving the child's life, the surgeon made a hasty cesarean section, cutting tissues, arteries and organs in the eagerness to save the valuable child-who, after all, happened to be a stillborn girl. The poor queen recovered conscience before finally dying in great agony".

The other sister of Pedro I, Princess Isabel Maria (1801-1876), also had epileptic seizures. The queen Dona Carlota Joaquina report to her on March $11^{\text {th }}, 1817$, apud Rangel': "I was very sad about the news from your second event as El Rey told me, and I think it is necessary that you take care of your health". Dom João VI had symptomatic convulsions followed by coma, and finally died (March $\left.4^{\text {th }}, 1826\right) 6$ days after ${ }^{2,3}$.

From the first marriage of Dom Pedro I with Princess Leopoldina, Carolina Josefa Leopoldina (1797-1826), seven children were born: Maria da Glória-1819-1853 (future Maria II of Portugal); Miguel (deceased soon after his birth); João Carlos (deceased at the age of 11 months); Januária Maria (1822-1901); Paula-Mariana (1823-1833); Francisca-Carolina (1824-1898), and Pedro II (1825$1891)^{8}$. Rangel ${ }^{7}$ reports febrile convulsions in Pedro II and Dona Januária, besides secondary epileptic seizures caused by lethal encephalitis in Dona Paula-Mariana. João Carlos also had symptomatic seizures, dying after a 28 hours long epileptic seizure, probably due to meningoencephalitis. It was said that Dona Leopoldina, had on her maternal side the "heavy perversions of the Bourbon of Naples and Spain..." . Princess Leopoldina was not aware at first of the epileptic condition of her husband, Dom Pedro I, although this situation was not strange to her, after all her brother, Prince Heir Ferdinand had also epilepsy. On December $11^{\text {th }}, 1826$, the Empress died, after violent alternating symptomatic convulsions "with nervous attacks and, despite, the best efforts of her doctors to save her-prescribing anti-septic, massages, bleedings, banns, laxative, antispasmodic and emetics" ${ }^{\text {. }}$. More facts about the epileptic seizures of Dom Pedro II can be found in the article by Gomes and Fontenelle ${ }^{4}$. Furthermore there is the account of the epileptic seizures of a bastard daughter of Dom Pedro $I^{5}$. Rangel ${ }^{7}$ also tells that the children of Dom Pedro II would have had seizures, some in the course of fatal cerebral disease. Dom Pedro II had four children: Alfonso Pedro (1845-1847), Isabel (1846-1921), Leopoldina (1847-1871) and Pedro Alfonso (1848-1850). The two male children died in convulsions ${ }^{7}$. The Princess Isabel, on May $30^{\text {th }}, 1847$, had seizures that lasted for three days, as tells Rangel ${ }^{7}$. The same author refers to a grandson of Dom Pedro II, Pedro Augusto, with febrile seizures ${ }^{4}$.

\section{The royal family epilepsy burden}

The multiple epileptic events in the royal family favor a hereditary origin. A reasonable interpretation for the clinical diversity of their fits is the existence of many epilepsy susceptibility genes, as well as modifier genes? One second possibility of inheritance could be the monogenic genes related to the heterogeneous group of the generalized idiopathic epilepsy. Kullmann ${ }^{9}$ remembers that the phenotypes associated with some genes can be remarkably diverse inside a family, even when the individuals have the same point mutation. This notable variability is consistent with a strong effect of modifier factors as when an only dominant epilepsy gene with high penetrance is transmitted. Another problem that affects the study of the transmission of these eventual genes in Dom Pedro's family is that they could function as susceptibility factors of epilepsy in its descendants, and so contributing to a generation skip. Still a third form of inheritance could be that of epilepsy associated to disorders that have seizures as one of the major features such as central nervous system malformation or genetic syndromes (for instance, tuberous sclerosis). Nevertheless such does not seem to be a reasonable possibility in Dom Pedro's family since all reports are far too benign. It is worth mentioning that medicine at that time recognized the common "nervous fevers", according to Broussais (1772-1838), could be associated to depression, "febris nervosa stupida", or with excitement and delirium, "febris nervosa versatilis" ${ }^{10}$. These fevers were common and its symptomatology could encompass fits of difficult differential diagnosis with epilepsy. Thus, there could have been an over diagnosis of epilepsy (actually, acute symptomatic epileptic seizures) in the Portuguese royal family. Rangel ${ }^{7}$, in a exaggerated way, glimpsed in almost all the members of the royal family the diagnosis of epilepsy, confusing it with symptomatic seizures due to cerebral insult or "nervous attacks" (psychiatric picture) common in Dona Carlota Joaquina, for instance. She mentioned that "My nervous attacks always follow me", apud Rangel ${ }^{7}$. 


\section{CONCLUSION}

The family history of D Pedro I is full of description of seizures and fits, febrile seizures, some severe symptomatic seizure events, besides psychogenic non-epileptic events, all characterized at that time as "nervous illnesses". Heterogeneity in the epileptic seizures is found in Dom Pedro's family. The seizures of Dom Pedro I's children may be linked to a syndrome described more recently: generalized epilepsy with febrile convulsion plus ${ }^{11}$. It encompasses (in some individuals and in some combinations) complicated febrile seizures, febrile seizures that persist beyond early childhood, generalized tonic-clonic afebrile seizures, atonic absence, myoclony and epileptic seizures of the temporal lobe.

ACKNOWLEDGMENTS - We acknowledge the collaboration of the staff libraries (Nacional, Academia de Brasileira de Letras, Real Gabinete Português de Leitura, Instituto Filosofia e Ciências Sociais-UFRJ and Faculdade de Letras-UFRJ) and Museu Imperial-Instituto do Patrimônio Histórico e Artístico Nacional-Ministério da Cultura (archives and library) for the consultation of books, periodicals and documents. We acknowledge the collaboration of Professor Alexandra Prufer de Queiroz Campos Araújo (UFRJ) who kindly reviewed the English.

\section{REFERENCES}

1. Souza OT. História dos fundadores do império do Brasil a vida de Dom Pedro I. 3a edição. Rio de Janeiro: Livraria José Olympio, 1957.

2. Gomes MM, Reimão R, Maranhão P Filho. Dom João VI's death: convulsions and coma. Arq Neuropsiquiatr 2007:65:1252-1255.

3. Gomes MM, Chalub M. Dom Pedro I of Brazil and IV of Portugal epilepsy and peculiar behavior. Arq Neuropsiquiatr 2007;65:710-715.

4. Gomes MM, Fontenelle LMC. The Emperor Dom Pedro II: his convulsive seizures when a boy. Arq Neuropsiquiatr 2007;65:1256-1259.

5. Gomes MM, Maia HS Filho. Epileptic seizures in a descendant of Dom Pedro I. Arq Neuropsiquiatr 2010;68:317-319.

6. Macaulay N. Dom Pedro: a luta pela liberdade no Brasil e em Portugal, 17981834. Tradução André Villalobos. Rio de Janeiro: Record, 1993.

7. Rangel A. O mal sagrado. In: Trasanteontem (Episódios e relatos históricos). São Paulo: Livraria Martins Editora, 1943.

8. Lamego L. Dom Pedro I, herói e enfermo. Rio de Janeiro: Livraria Editora Zélio Valverde, 1939

9. Kullmann DM. Genetics of epilepsy. J Neurol Neurosurg Psychiatry 2002;73: 32-35.

10. Santos LC Filho. Patologia e terapêutica. In: História geral da Medicina brasileira. São Paulo: Hucitec EDUSP, 1991

11. Nordli DR Jr. Idiopathic generalized epilepsies recognized by the International League Against Epilepsy. Epilepsia 2005;46(Suppl 9):S48-S56. 